\title{
SANDFLIES (DIPTERA: PSYCHODIDAE) OF THE AMAZÔNIA OF MARANHÃO. V. SEASONAL OCCURRENCE IN ANCIENT COLONIZATION AREA AND ENDEMIC FOR CUTANEOUS LEISHMANIASIS
}

\author{
REBÊLO, J. M. M., ${ }^{1}$ OLIVEIRA, S. T. de, ${ }^{2}$ SILVA, F. S., ${ }^{2}$ BARROS, V. L. L. ${ }^{3}$ and \\ COSTA, J. M. L. ${ }^{2}$ \\ ${ }^{1}$ Departamento de Biologia, Universidade Federal do Maranhão, Campus Universitário do Bacanga, Avenida dos \\ Portugueses s/n, CEP 65080-040, São Luís, MA, Brazil \\ ${ }^{2}$ Núcleo de Patologia Tropical e Medicina Social, Departamento de Patologia, Universidade Federal do Maranhão, \\ Praça Madre Deus, no 02, CEP 65025-560, São Luís, MA, Brazil \\ ${ }^{3}$ Departamento de Biologia, Universidade Estadual do Maranhão, Campus Universitário Paulo VI, Tirirical, \\ São Luís, MA, Brazil \\ Correspondence to: José Manuel Macário Rebêlo, Departamento de Patologia, Universidade Federal do Maranhão, \\ Praça Madre Deus, no 02, CEP 65025-560, São Luís, MA, Brazil \\ Received September 22, 1999 - Accepted April 28, 2000 - Distributed February 28, 2001
}

(With 4 figures)

\begin{abstract}
In this paper, the seasonal abundance of 25 sandfly species (1 of the Brumptomyia genus and 24 of the Lutzomyia genus) found at P1V5, municipal district of Buriticupu, Maranhão State, is discussed. The capture was carried out from 18:00 P.M. to 6:00 A.M., once a month, from January to December 1996. CDC light traps were set up in the forest, in the peri and intradomicile environments. Five species were only found in the rainy season (January to June), being represented by one or two individuals; eight species occurred only in the dry season (July to December) and eleven species appeared in both seasons. The most frequent species in the dry period were: L. whitmani $(26.3 \%)$, L. serrana (23\%), L. choti (22.8\%), L. evandroi (7.5\%), L. longipalpis (5.8\%), L. termitophila (3.3\%), L. shannoni (3\%) and L. migonei (2.5\%). In the rainy season, $L$. whitmani was the prevailing species (74\%), followed by $L$. termitophila (4\%), L. umbratilis $(3.4 \%)$, L. serrana $(2.8 \%)$, L. evandroi $(2,8 \%)$ and $L$. claustrei (2.4\%). L. whitmani was thought to be an annual species, occurring in the entire year of study. The others species, with exception to L. serrana and L. evandroi, showed a seasonal, punctual or peripheric pattern.
\end{abstract}

Key words: Phlebotominae, Lutzomyia, Leishmaniasis, Amazônia of Maranhão.

\section{RESUMO}

Flebotomíneos (Diptera: Psychodidae) da Amazônia maranhense. V. flutuação sazonal em área de colonização antiga e de endemismo de leishmaniose cutânea

Discute-se neste trabalho a abundância sazonal de 25 espécies de flebótomos (um do gênero Brumptomyia e 24 do gênero Lutzomyia) encontradas na localidade de P1V5, município de Buriticupu. Os flebótomos foram capturados das 18 às 6 horas, uma vez por mês, de janeiro a dezembro de 1996. Utilizaram-se armadilhas luminosas CDC, instaladas na mata, peri e intradomicílio. Os flebotomíneos foram encontrados o ano inteiro, sendo que cinco espécies distribuíram-se somente na estação chuvosa (janeiro a junho), representadas por um ou dois indivíduos; oito espécies só ocorreram na estação seca (julho a dezembro) e 12 espécies tiveram representantes nas duas estações. No período seco foram encontrados 400 espécimens, e as espécies mais abundantes foram: L. whitmani $(26,3 \%), L$. serrana (23\%), L. choti (22,8\%), L. evandroi (7,5\%), L. longipalpis (5,8\%), L. termitophila $(3,3 \%)$, L. shannoni 
(3\%) e L. migonei (2,5\%). Já na estação chuvosa, foram capturados 327 espécimens e o predomínio foi das espécies L. whitmani (74\%), L. termitophila (4\%), L. umbratilis (3,4\%), L. serrana (2,8\%), L. evandroi $(2,8 \%)$ e L. claustrei $(2,4 \%)$. Foram consideradas anuais as espécies L. whitmani, que ocorreram em todos os meses do ano de estudo, e L. serrana e L. evandroi, que faltaram apenas em três meses alternados. As demais foram consideradas sazonais, periféricas ou pontuais. Considerando todos os indivíduos capturados por estação, verifica-se que a densidade foi significativamente maior no período seco $(55 \%)$ do que no período chuvoso $(45 \%)$. Durante o período de captura dos flebotomíneos notificou-se a ocorrência de 384 casos de LTA na região de Buriticupu e, a exemplo do que ocorreu com os flebotomíneos, cerca de $53,4 \%$ dos casos da doença foram registrados na estação seca, contra 46,6\% na estação chuvosa.

Palavras-chave: Phlebotominae, Lutzomyia, Leishmaniose, Amazônia maranhense.

\section{INTRODUCTION}

In the hot and wet tropical regions in which a regular pluvial distribution takes place, the sandflies density presents little variation per year (Le Pont \& Pajot, 1980). Otherwise, in the temperate and subtropical areas the density fluctuation follows a season pattern, increasing during the hot and wet period and decreasing softly in the could and dry one (Consolim et al., 1990; Gomes et al., 1983).

In Maranhão State, where a hot and moist climate is found, little is known about sandflies season pattern. The only published data on this approach were shown by Rebêlo et al. (1999a) studying the association between the sandflies occurrence in every month and the distribution of visceral and cutaneous leishmaniasis in the eastern "cerrados" in Maranhão State, however based on fragmentary data taken from the National Foundation of Health/FNS/MA. These authors found out that the sandfly species were present in the most studied months, evidencing a significant frequency in the rainy season (January-June).

Studies of the sandflies fauna undertaken in Maranhão State are limited to inventory works aimed only at knowing the local species composition. Works dealing with sandfly fauna have been carried out in distinct areas in the State, such as the "cerrados" zone and the island of São Luís (Rebêlo et al., 1996, 1999a, b). Currently, these studies have been established in endemic areas for leishmaniasis, as in the Amazônia of Maranhão in more than 40 Lutzomyia species have been found (Rebêlo et al., 1998).

The municipality of Buriticupu, situated in the Amazônia of Maranhão, takes part in the ende- mic areas for cutaneous leishmaniasis in Maranhão and it has been contributing in the last four years with over 300 annual human cases, according to available reports from a local Health Post of the Federal University of Maranhão. Although these circumstances, studies dealing with the regional sandfly and infection ecology are still lacking.

The understanding about season distribution of the sandflies is a valuable tool not just from the bioecology viewpoint of these insects but also regarding the epidemiological aspects of the disease and thus providing subsidies to leishmaniasis control measures.

This work focuses mainly on assessing the monthly distribution pattern of the phlebotomine sandflies in the Buriticupu region associated with the occurrence of human cases of cutaneous leishmaniasis throughout the year.

\section{MATERIAL AND METHODS}

\section{Study area}

The municipality of Buriticupu is situated at $4^{\circ}$ and $5^{\circ} \mathrm{LS}$ and $45^{\circ} 30^{\prime}$ and $47^{\circ} \mathrm{LW}$ in the Amazônia of Maranhão (Fig. 1) at a mean altitude of $200 \mathrm{~m}$. The hot and wet is the characteristic weather, however, associated with a transition between the Amazonia super-humid and the semi-arid northeastern weather. There is a 6-month dry season and an annual mean precipitation of $1,800 \mathrm{~mm}$ (IBGE, 1984).

The vegetation encountered in Buriticupu is represented by the Dense Perennial Stationery Forest, comprised of huge trees which may extent up to $50 \mathrm{~m}$ from the ground and it stays on high and low sedimentary areas (IBGE, 1984). 


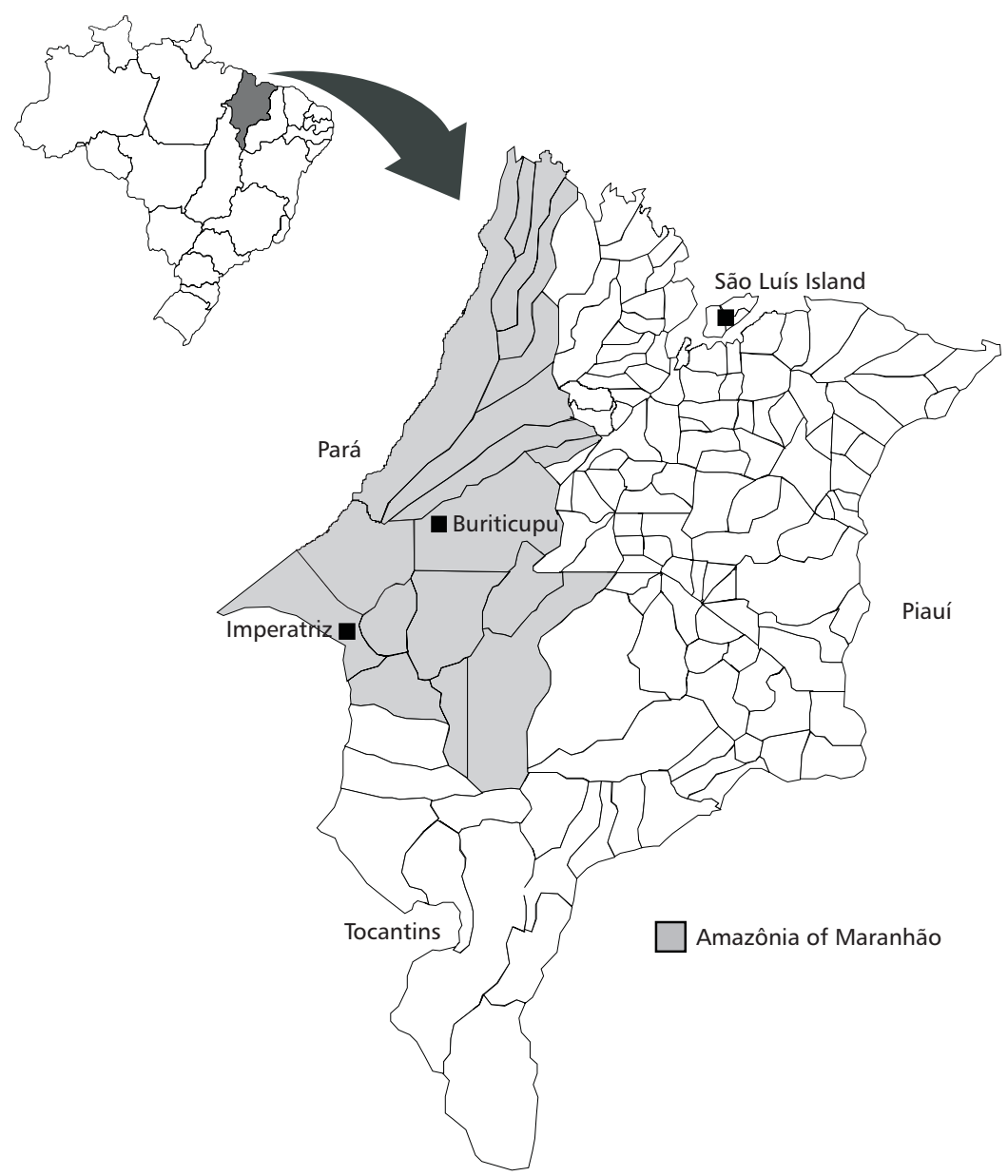

Fig. 1 - A map of Maranhão State showing the position of Buriticupu in the Amazônia of Maranhão, Brazil.

However, owing to the exploitation activities and agricultural projects a variety of predominant forest profiles are found, such as "capoeiras" forests, grazing areas and shrubby species of disturbed timberlands. In the past, shrubby areas were absent, and the present small sized plants and halfgrown trees are ensuing from the adjacent matrixes. The original vegetation, to date, is delineated by isolated fragments of forest on the plateaus.

The actual study area (about 12 hectares) where the sandflies collecting was accomplished which includes the domestic and peridomestic sites (pigpen and poultry yards) is placed on a fragment of forest far $50 \mathrm{~km}$ from the municipality of Buriticupu and $20 \mathrm{~km}$ from the P1V5 locality.

\section{Collecting method}

Sandflies were collected between 18:00 and 6:00 hours, once a month, from January to December 1996 in the forest, inside and outside environments. In the forest one CDC light trap was used and manual collections were also made by using a Shannon trap. At the peridomestic site two CDC light traps were used, one in the poultry yards and the other in the pigpen, both placed about $30 \mathrm{~m}$ from the human dwellings. In the intradomestic environment two CDC light traps were set up in the bedrooms. The light traps were hooked at $1.5 \mathrm{~m}$ above the ground and always at the same places.

The collected specimens in every light trap and hour were killed in recipients with ethyl acetate 
and deposited in glasses containing 70\% alcohol for further transport to the laboratory. In the laboratory they were mounted in Berlese for the identification procedure according to Young \& Duncan (1994). Schedules were filled with the species name, site, method of capture, date, hour and the catcher's name.

A non-parametric statistical test was used for analyzing the differences found between rainy and dry season sandfly density. The differences were thought to be statically significant when only the error probability (p) was lower than $5 \%(\mathrm{p}<0.05)$.
The simple correlation coefficient was utilized for analyzing the association between the sandfly monthly variation and the temperature, moist and pluvial precipitation deviation along the year.

\section{RESULTS}

A total of 727 specimens of 25 sandfly species ( 1 of the genus Brumptomyia and 24 of the genus Lutzomyia) were encountered. The monthly distribution of the collected species is depicted in Table 1.

TABLE 1

Monthly frequency of the Phlebotominae species encountered in the forest and in the human dwellings (intra e peridomicile environments), in P1V5 locality, Buriticupu, Amazônia of Maranhão, Brazil, 1996.

\begin{tabular}{|c|c|c|c|c|c|c|c|c|c|c|c|c|c|}
\hline Seasons & \multicolumn{6}{|c|}{ Rainy } & \multicolumn{6}{|c|}{ Dry } & \multirow[b]{2}{*}{ Total } \\
\hline Months & $\mathbf{J}$ & $\mathbf{F}$ & M & $\mathbf{A}$ & $\mathbf{M}$ & $\mathbf{J}$ & $\mathbf{J}$ & $\mathbf{A}$ & $\mathbf{S}$ & $\mathbf{O}$ & $\mathbf{N}$ & D & \\
\hline B. avellari & - & 3 & - & - & - & - & - & 2 & - & - & - & - & 5 \\
\hline L. brachyphalla & - & - & - & - & - & 2 & - & - & - & - & - & - & 2 \\
\hline L. choti & - & - & - & - & - & - & 5 & 10 & 14 & 11 & 41 & 10 & 91 \\
\hline L. claustrei & - & - & - & 1 & 7 & 1 & - & - & - & - & - & - & 9 \\
\hline L. dendrophyla & - & 1 & - & - & - & 1 & - & - & - & - & - & - & 2 \\
\hline L. evandroi & 4 & 2 & - & - & - & 3 & 2 & 4 & 1 & 4 & 7 & 12 & 39 \\
\hline L. furcata & - & - & - & - & - & 2 & 1 & 3 & 1 & - & - & - & 7 \\
\hline L. goiana & - & - & - & - & - & - & 1 & 1 & - & - & - & - & 2 \\
\hline L. gomezi & - & 1 & - & - & - & - & 1 & - & - & - & - & - & 2 \\
\hline L. hirsuta & - & - & - & - & 2 & - & - & - & - & - & - & - & 2 \\
\hline L. lenti & - & - & - & - & - & - & - & - & - & - & - & 1 & 1 \\
\hline L. lloydi & - & - & - & - & 1 & - & - & - & - & - & - & - & 1 \\
\hline L. longipalpis & - & - & - & - & - & - & - & 6 & 7 & - & 1 & 11 & 23 \\
\hline L. migonei & - & - & - & 1 & - & - & - & - & - & 5 & 5 & - & 11 \\
\hline L. monstruosa & - & - & - & - & - & 1 & - & - & - & - & - & - & 1 \\
\hline L. sordellii & - & - & - & - & - & - & - & 1 & - & - & - & - & 1 \\
\hline L. serrana & 2 & 3 & 2 & 1 & - & 1 & - & 3 & 29 & 51 & 8 & 1 & 101 \\
\hline L. shannoni & - & - & - & - & - & 11 & - & - & - & 10 & 1 & 1 & 23 \\
\hline L. spathotrichia & - & - & - & - & - & - & - & - & - & 1 & - & - & 1 \\
\hline L. termitophila & 4 & 5 & 3 & 1 & - & - & 2 & 1 & - & - & - & 10 & 26 \\
\hline L. triacantha & - & - & - & - & - & - & - & 2 & - & - & - & - & 2 \\
\hline L. trinidadensis & - & 1 & - & - & - & 2 & - & 1 & - & - & - & - & 4 \\
\hline L. trispinosa & - & - & - & - & 1 & 1 & 1 & 1 & 1 & 3 & - & - & 8 \\
\hline L. umbratilis & - & - & - & - & 7 & 7 & 1 & - & - & - & - & - & 14 \\
\hline L. whitmani & 3 & 9 & 65 & 116 & 39 & 10 & 2 & 41 & 42 & 12 & 5 & 3 & 347 \\
\hline Total of individuals & 13 & 25 & 70 & 120 & 57 & 42 & 16 & 76 & 94 & 97 & 68 & 49 & 727 \\
\hline$\%$ individuals & \multicolumn{6}{|c|}{$55 \%$} & \multicolumn{6}{|c|}{$45 \%$} & \\
\hline Species & 4 & 8 & 3 & 5 & 6 & 12 & 9 & 13 & 7 & 8 & 7 & 8 & \\
\hline
\end{tabular}


The sandfly species were present in the whole year of study however 5, represented by one or two individuals, were found only in the rainy season (January-June) and; 8 species appeared exclusively in the dry season (July-December); 12 species were present in both seasons. From combining the species which registers were displayed in only one season with those occurring in both seasons the following results could be obtained:

- in the rainy season it was found 18 species in a total of 327 collected individuals, where $L$. whitmani $(74 \%)$ was the prevalent species followed in a fewer frequency by L. termitophila (4\%), L. umbratilis (3.4\%) (Fig. 2A);
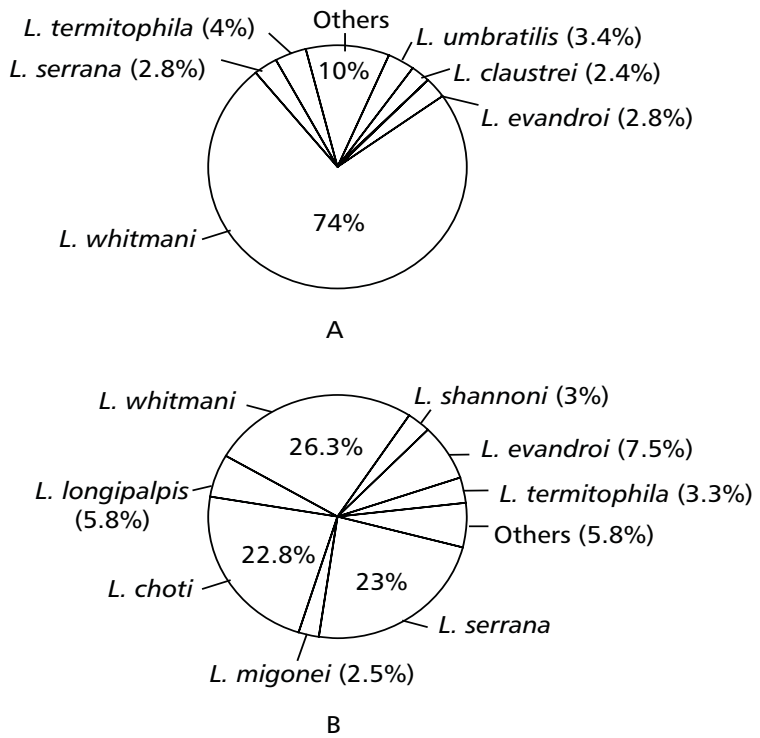

Fig. 2 - Specimens rate numbers of sandflies collected in the rainy (A) and dry (B) seasons, in P1V5 locality, Buriticupu, Amazônia of Maranhão, Brazil, 1996.

- in the dry season 20 species were registered in a total of 400 collected individuals. $L$. whitmani $(26.3 \%)$ continued prevailing, however the two succeeding places were occupied by $L$. serrana $(23 \%)$ and L. choti $(22.8 \%)$, respectively. The relative amount of the others species in this period can be seen in Fig. 2B.

It is observable that $L$. whitmani was the most frequent species in both seasons mainly in the rainy one since about $3 / 4$ of the collected individuals was represented by this species (Fig. 2A). This sandfly appeared in the entire year showing a relatively high number of individuals in most months but chiefly in April which was one of the rainiest month of the research period (Table 1).

The presence of L. serrana and L. evandroi is displayed in both seasons, being relatively found in the whole year only lacking in two or three months; the former was the most regular one and the latter had a tendency to occur more abundantly in the dry period (Table 1).

The others sandflies were found in a given month or season and some species occurred irregularly throughout the year. On this basis, the species B. avellari, L. brachyphalla, L. hirsuta, L. lloydi, L. monstruosa, L. sordellii, L. spathotrichia, L. lenti and L. triacantha were classified as punctual due to the occurrence in only one month.

L. dendrophyla, L. gomezi and L. trinidadensis were though to be peripheric, as they were encountered irregularly in two or three months during the year.

Otherwise, L. choti, L. claustrei, L. furcata, L. trispinosa and L. umbratilis were grouped as seasonal species since their occurrence was restrained to a strict and continuos period of the year.

The individual monthly distribution curves of all assembled species and the environmental 
variables are illustrated in Fig. 3. The simple correlation coefficient showed a decreased association between the monthly variation of the sandflies and the temperature $(\mathrm{r}=0.47)$ and relative moisture changes $(r=0.11)$ and a lower monthly deviation of the pluvial precipitation was revealed.

On the other hand, taking all collected individuals for each season into consideration, one can observe a raised density in the dry period where 400 specimens were captured, totaling $55 \%$ of the total sample, resulting in a $10 \%$ rate which was greater than that found in the rainy season (327 specimens or $45 \%$ of the sample) (Table 1). This difference was thought to be statistically significant ( $\mathrm{p}>0.05)$.
An inventory of human cases of leishmaniasis was made parallel to the sandflies collecting course, resulting in 384 notified cases in the Buriticupu region. About $53.4 \%$ of the human cases was registered in the rainy season and $46.6 \%$ in the dry period. The seasonal distribution pattern of the human cases of cutaneous leishmaniasis was associated with the individual abundance described above.

In Fig. 4 it is depicted the monthly distribution of the cases of cutaneous leishmaniasis correlated to the captured sandflies. The simple correlation coefficient made evident the existence of a strong association between the two variables $(\mathrm{r}=0.64)$.
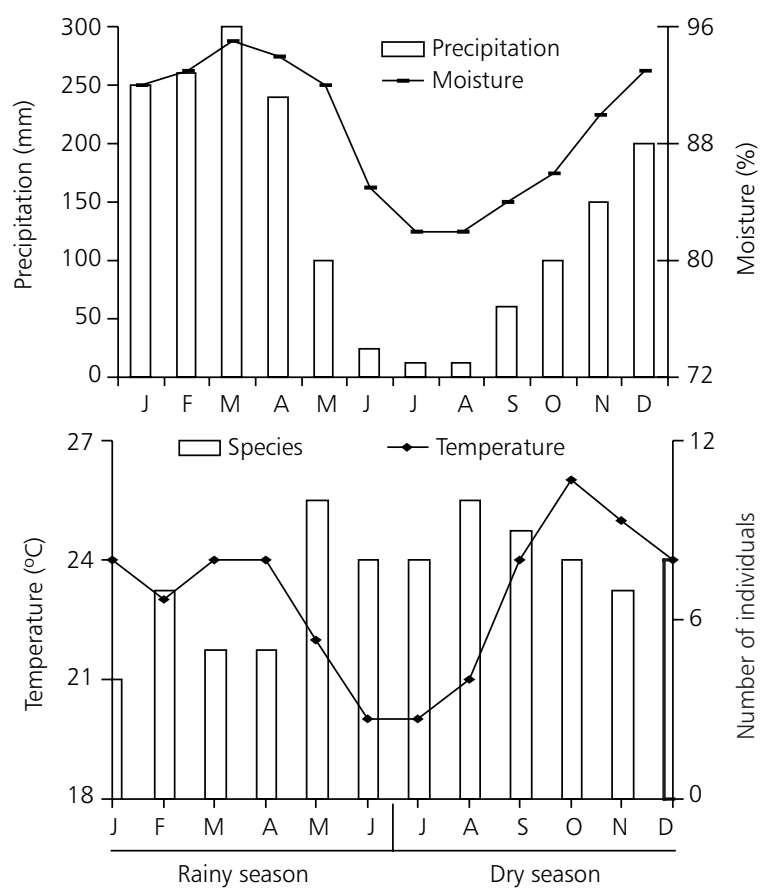

Fig. 3 - Monthly variation in the number of phlebotomine species and in the relative moisture, pluvial precipitation and temperature indexes, in the municipality of Buriticupu, MA, Brazil, from January to December 1996.

\section{DISCUSSION}

In this study, the sandflies showed distinct profiles of distribution throughout the year. It was found species to have an annual, seasonal, peripheic or punctual behavior. Generally, the two latter behaviors tend to prevail upon the others in in- ventory works carried out in different areas in Brazil such as in Buriticupu. Among the phlebotomine sandflies present in Buriticupu, attention is given to L. whitmani the only species classified clearly as annual and together with $L$. serrana and $L$. evandroi, which were absent in three subsequent months, were the most frequent sandflies. 


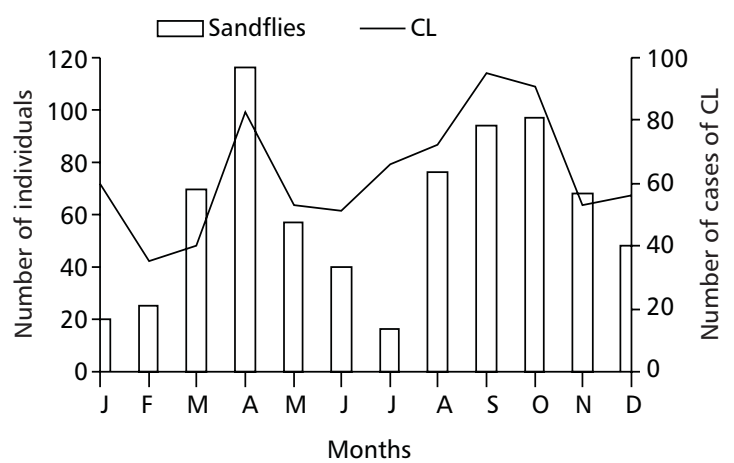

Fig. 4 - Monthly variation in the total of phlebotomine species collected in the rural community of P1V5 and in the number of notified human cases of cutaneous leishmaniasis (CL) in Buriticupu, MA, Brazil, 1996.

Otherwise, in "cerrados" zone of Maranhão where a drier weather is found, L. whitmani and L. evandroi were encountered only in six months of study. The former was more frequent in the wetter period (Rebêlo et al., 1999a) and the latter was present in both seasons. The species more irregularly distributed in that region was L. longipalpis, not so surprisingly since that area is endemic for visceral leishmaniasis.

The Buriticupu region, which is an endemic area for cutaneous leishmaniasis, $L$. whitmani was found to be the prevailing species represented by over $50 \%$ of the collected individuals and it was prevalent in the rainy season, since in this period more than $69 \%$ of the individuals were sampled. The high populational density of $L$. whitmani in the whole year should be faced as an epidemiological factor directly associated with the risk of leishmaniasis transmission, whereas the notified cases was uniform in all surveyed months. According to Barnett (1962) the spatial and temporal relationship between an arthropod and the disease is an essential factor for incriminating a given species as an effective vector of this corresponding affection. This approach have been an important element applied to the studies carried out in the Buriticupu region.

In the neighboring Pará State, L. whitmani is shown to be the vector of Leishmania shawi (Ryan et al., 1987; Lainson et al., 1994) and in the brazilian areas out of the amazonian domain this species has been incriminated as the vector of Le. braziliensis. There are some reports from the northern of Brazil dealing with these conclusions (Hock et al., 1986; Ryan et al., 1990; Aze- vedo et al., 1990; Queiroz et al., 1991). Interestingly, these two forms of leishmania has already been detected in Buriticupu, not isolated from the vector but from patients bearing ulcerated lesions of cutaneous leishmaniasis.

It should be pointed out the high frequency of $L$. whitmani in the sylvatic environment in Buriticupu. This behavior is similar to that found in the Amazônia of Pará where this sandfly neither exhibit any anthropophili nor invade the human dwellings near the forest (Rangel et al., 1996). This species has been commonly found at the peridomestic environment in a great abundance being comparable to the States of São Paulo and Minas Gerais, where in endemic areas for cutaneous leishmaniasis, this sandfly has shown elevated density with markedly inclination to bite man (Taniguchi et al., 1991; Tolezano et al., 1992). From the bioecology viewpoint the $L$. whitmani population in Buriticupu has been getting to an intermediate behavior between the sylvatic and the brazilian southern peridomestic populations.

Among the seasonal species, $L$. umbratilis is a predominant species and the major vector of L. guyanensis from Manaus until Amapá and French Guyana, while L. whitmani is thought to be a secondary species. A noteworthy fact is that although the presence of this species in Buriticupu is well known, since then no isolation of Le. guyanensis from patients bearings lesions has been obtained. Regardless, the presence of this sandfly species, even though in a short period in the year, supports the hypothesis that leishmaniasis in Buriticupu have been transmitted by more than one sandfly vector. 
In general, the sandflies overall pattern of occurrence in P1V5 community was similar to that found in tropical humid areas where, with little exceptions, the phlebotomine species showed to have representative individuals all the year (Le Pont \& Pajot, 1980). According to the findings acquired from this present work, a clear variation in the number of sandflies encountered in both seasons (dry and rainy) was not observed, as frequently found in the subtropical areas, where most species tends to appear in the hotter and humid months (Gomes \& Galati, 1977; Teodoro et al., 1993), even with the existence of species presenting a high density in the drier and colder months (Consolim et al., 1990; Gomes et al., 1983). In other way, a large amount of sandfly can be found in any period of the year in P1V5, regardless the season.

With regard to the populational density, little variations occurred but when taking the rainy season into account this variations were most frequently found, reflecting in the low collecting rate in both January and February. Such variations should not be thought as an exception to the sandfly occurrence pattern in the tropical areas. The longterm rainy or blustering rainfall periods act very greatly upon the small insect population like sandfly, forcing them to remain sheltered in such conditions. In the rainless days of the rainy period a large amount of sandflies could be found, as occurred in June.

Finely, one should be aware of the leishmaniasis human cases continuously present in the Buriticupu region. On this work, new cases of human infection were detected in all months in 1996. These data compel us to state that the leishmanial transmission process occurs at any time, regardless the season and also by the fact that the continuos presence of L. whitmani and the alternated presence of $L$. umbratilis and L. migonei, more than one sandfly vector exists in that area. Nevertheless, judging from the occurrence pattern, it is likely that the most notified human cases of leishmaniasis in Buriticupu has been transmitted by $L$. whitmani, the only species attracted to traps during all the year and in high density detected in most studied months.

Acknowledgments - We are grateful to the P1V5 community in Buriticupu, represented by Pedro and Bernardo, the forester and the community leader, respectively.

\section{REFERENCES}

AZEVEDO, A. C. R., RANGEL, E. F., COSTA, M. E., DAVID, J., VASCONCELOS, A. W. \& LOPES, U. G., 1990, Natural infection of Lutzomyia (Nyssomyia) whitmani (Antunes \& Coutinho, 1939) by Leishmania of the Braziliensis complex in Baturité, Ceará State, Northeast Brazil. Mem. Inst. Oswaldo Cruz, 85: 251.

BARNETT, H. C., 1962, The incrimination of arthropods as vectores of desease. XI Intem. Kongress Entom. Wien., 1960. Sonderdruck aus den Verhandlungen, 2: 341-345.

CONSOLIM, J. et al., 1990, Flebótomos da área do reservatório da hidrelétrica de Itaipu, Estado do Paraná, Brasil (Diptera, Psychodidae). Cad. Saúde Públ., 6: 7485.

GOMES, A. C. \& GALATI, E. A. B., 1977, Flebotomíneos de Londrina, Paraná (Brasil), e observações ecológicas sobre algumas espécies. Rev. Saúde Públ., 11: 28487.

GOMES et al., 1983, Aspectos ecológicos da leishmaniose tegumentar americana. 3. Observações naturais sobre o ritmo diário de atividade de Ps. Intermedius em ambiente florestal e extraflorestal. Rev. Saúde Públ., 16: $149-59$.

HOCK, A., RYAN, L., VEXENAT, J. A., ROSA, A. C. \& BARRETO, A. C., 1986, Isolation of Leishmania braziliensis braziliensis and other trypanosomatids from Phlebotomine in a mucocutaneous leishmaniasis endemic area, Bahia, Brazil. Mem. Inst. Oswaldo Cruz, 81: 63.

INSTITUTO BRASILEIRO DE GEOGRAFIA E ESTATÍSTICA, 1984, Atlas do Maranhão. Edição em convênio com o Governo do Estado do Maranhão, Rio de Janeiro, 104p.

LAINSON, R., SHAW, J. J., SILVEIRA, F. T., SOUZA, A. A. A., BRAGA, R. R. \& ISHIKAWA, E. A. Y., 1994, The dermal leishmaniases of Brazil, with special reference to the eco-epidemiology of the disease in Amazônia. Mem. Inst. Oswaldo Cruz, 89: 435-443.

LE PONT, F. \& PAJOT, F. X., 1980, La leishmaniase en Guyane Française. 1. Étude de l'ecologie et du taux infection naturelle du vecteur Lutzomyia umbratilis Ward e Fraiha, 1977 en saison séche. Cah. O.R.S.T.O.M. Sér. Ent. Méd. Parasit., 18: 369-82.

QUEIROZ, R. G., VASCONCELOS, I. A., VASCONCELOS, A. W., SOUZA, R. N. \& DAVID, J., 1991, New World phlebotomine sandflies as hosts of Leishmania (V.) braziliensis in na endemic area for cutaneous leishmaniasis in Ceará State, Northeast Brazil. First International Symposium on Phlebotomine Sandflies, Rome, 87p.

RANGEL, E. F., LAINSON, R., SOUZA, A. A., READY, P. \& AZEVEDO, A. C. R., 1996, Variation between geographical populations of Lutzomyia (Nyssomyia) whitmani (Antunes \& Coutinho, 1939) sensu lato (Diptera: Psychodidae: Phlebotominae) in Brazil. Mem. Inst. Oswaldo Cruz, 91: 43-50. 
REBÊLO, J. M. M., MENDES, W. A., COSTA, J. M. L. \& CAVALEIRO, N., 1996, Lista preliminar das espécies do gênero Lutzomyia França 1924 (Psychodidae, Phlebotominae) do Estado do Maranhão, Brasil. Cad. Saúde Púb., 12: 545-549.

REBÊLO, J. M. M., OLIVEIRA, S. T., BARROS, V. L. L. \& SILVA, F. S., 1998, Sandflies (Diptera, Psychodidae) in area of leishmaniasis. Distribution of the species in deforested area in the Amazônia of Maranhão. Mem. Inst. Oswaldo Cruz, VE-60: 343.

REBÊLO, J. M. M., LEONARDO, F. S., COSTA, J. M. L., PEREIRA, Y. N. O. \& SILVA, S. F., 1999a, Flebótomos (Lutzomyia, Phlebotominae) em área endêmica de leishmaniose na região dos cerrados do Estado do Maranhão, Brasil. Cad. Saúde Púb., 15: 133-141.

RebÊlo, J. M. M., ARAúJo, J. C., CARVAlho, M. L., BARROS, V. L. L., SILVA, F. S. \& OLIVEIRA, S. T., 1999b, Flebótomos (Diptera, Phlebotominae) da Ilha de São Luís, zona do golfão maranhense. Rev. Soc. Bras. Med. Trop., 32: 247-253.

RYAN, L., LAINSON, R., SHAW, J. J., BRAGA, R. R. \& ISHIKAWA, E. A., 1987, Leishmaniasis in Brazil. XXV. Sandfly vectors of Leishmania in Para State, Brazil. Med. Vet. Entomol., 1: 383-395.

RYAN, L., VEXENAT, J. A., MARSDEN, P. D., LAINSON, R. \& SHAW, J. J., 1990, The importance of rapid diagnosis of new cases of cutaneous leishmaniasis in pinpointing the sandfly vector. Trans. R. Soc. Trop. Med. Hyg., 84: 786.
TANIGUCHI, H. H., TOLEZANO, J. E., CORREA, F. M. A., MORAES, R. H. P. \& VEIGA, R. M., 1991, Epidemiologia da leishmaniose americana no Estado de São Paulo, Brasil. 1. Composição da fauna flebotomínica no município de São Roque, região de Sorocaba. Rev. Inst. Adolfo Lutz, 51: 23-30.

TEODORO, U., SALVIA FILHO, V., LIMA, E. M., SPINOSA, R. P., BARBOSA, A. C., FERREIRA, M. E. M. C. \& SILVEIRA, T. G. V., 1993, Flebotomíneos em área de transmissão de leishmaniose tegumentar na região norte do Estado do Paraná, Brasil: Seasonal variation and nocturnal activity. Rev. Saúde Públ., 27: 190-194.

TOLEZANO, J. E., NOVELLI, M. A. \& TANIGUCHI, H. H., 1992, Leishmaniose tegumentar no Estado de São Paulo. VI. Avaliação do comportamento antropofílico de flebotomíneos em áreas endêmicas. Mem. Inst. Oswaldo Cruz, 87(Suppl.): 219.

YOUNG, D. G. \& DUNCAN, M. A., 1994, Guide to the identification and geographic distribution of Lutzomyia sand flies in Mexico, the West Indies; Central and South America (Diptera Psychodidae). Gainesville, Florida, 881p. 